\title{
DO FUNDING RESOURCES AFFECT THE ACCOUNTABILITY DISCLOSURE OF NON- PROFIT ORGANIZATIONS?
}

\author{
Nik Amalena Najebah Nik Azman*, \\ Roshayani Arshad and Noorbijan Abu Bakar
}

\begin{abstract}
Accountability is important in Non-profit Organizations (NPOs) since their key revenue resources are donations and contributions from the public and various parties. This implies that NPOs are accountable to various stakeholders. In Malaysia, the growing number of NPOs shows how important NPOs are in contributing to society in terms of social work. By championing the need of the people through their activities, NPOs enjoy public trust since their goal is to help the people, and not for profit motivation. However, many NPOs are generally reluctant to share more comprehensive information and may not recognize the need for accountability by the NPOs. These problems could be solved if the enforcement and monitoring mechanisms are efficiently practiced. Using content analysis of annual reports and the Financial Information Forms/Borang Maklumat Kewangan (BMK) of 219 societies registered with the Companies Commission of Malaysia (CCM), this study examines the relationship between organizational characteristics and accountability in NPOs. The characteristics of organizational characteristics examined are grants and donations. The resource dependency theory is used to explain the organizational characteristics. The results of this study provide evidence that organizational characteristics are not significantly related to the accountability of NPOs. In relation to the insignificant results for organizational characteristics, it may indicate that nonprofit managers are not using their disclosure effectively to manage interorganizational relationships to ensure the continuous flow of financial and other resources to their organizations. Overall, the findings provide useful information that gives more input to the various regulatory authorities and other relevant stakeholders concerning the accountability disclosure of NPOs in Malaysia.
\end{abstract}

Keywords: Accountability; Donation; Grant; Resource Dependency Theory; Nonprofit Organization

JEL classification: L31, L39

*Corresponding author: Nik Amalena Najebah Nik Azman is a Lecturer at the Department of Accounting, Universiti Tenaga Nasional, 26810 Muadzam Shah, Pahang, Malaysia. Email: Amalena @uniten.edu.my. Roshayani Arshad is an Associate Professor and Deputy Director (Postgraduate \& Innovation) of Accounting Research Institute (ARI), Universiti Teknologi MARA, 40450 Shah Alam, Selangor, Malaysia.Email: roshayani@salam.uitm.edu.my

Noorbijan Abu Bakar are an Associate Professor at the Faculty of Accountancy, Universiti Teknologi MARA, 42300 Bandar Puncak Alam, Selangor, Malaysia. Email: norbi374@ salam.uitm.edu.my 


\section{Introduction}

The Malaysian Code on Corporate Governance (MCCG) was an important landmark in Corporate Governance reform in Malaysia. The MCCG provides the guidelines for principles and best governance practices that emphasize the importance of transparency, accountability, internal control, and board composition. Corporate Governance serves as a mechanism that assists firms to achieve their objectives while disclosure is an essential tool for reporting their corporate performance to investors. This is to ensure the accountability of the organization in conducting the operations. Thus, having good governance is important to reduce information asymmetry as well as enhance accountability disclosure.

The rapid development in respect of the quantity, control and effectiveness of NPOs has produced greater demands for NPO accountability and governance (Brown, 2008). This, in turn, has increased the demand for accountability in NPOs (Brown and Moore, 2001). These demands originated from numerous areas including government, regulatory bodies, professional bodies, sponsors, donors, the media, volunteers and the general public. Hence, accountability is a critical value in NPOs to structure the foundation for both legitimacy and to support the non-profit needs to carry out their work.

When considering the term accountability, much of the scholarly and policy literature on non-profit accountability focuses on why this issue has risen to prominence and prescribes appropriate responses and models. Leat (1988) and Schmitz (2011) stated that several key questions need to be addressed. In their research, they identified several key questions concerning accountability, specifically, what is accountability? Who are the voluntary organizations accountable to? What do they give account for? How are they accountable?

\section{Literature Review}

\subsection{Accountability in Non-Profit Organizations}

Accountability in NPOs is generally referred to as the organizational responsibility to various stakeholders. This relates to the responsibility of the NPOs to adopt best practices concerning governing the NPOs and prevent money laundering, terrorism financing and other fraudulent activities, as recommended by advocates in the non-profit sector.

In Malaysia, one of the relevant authorities is the Asia Pacific Group (APG). Malaysia became a member of the APG on 31 May 2000, and, as a consequence, it is required to implement and comply with the recommendations of the Financial Action Task Force (FATF). The FATF is a policy-making body that was established in 1989 and is responsible for generating political will in the development of legislative and political reforms in the areas of anti-money laundering and terrorism financing. Assessment concerning compliance with the recommended practices by the FATF in the Asia Pacific region is performed by the APG. 
Non-compliance can result in a member country being blacklisted and subjected to various sanctions, such as economic sanctions, trade restrictions and a higher level of scrutiny with a consequent negative perception of the NPO sector. Hence, it is important to identify whether NPOs in Malaysia are accountable and adopting the recommended measures for safeguarding the NPOs and the members, as well as the public at large.

Accountability can also be viewed from a funder's perspective, which involves ensuring that outcomes are met and that the organization has a system for monitoring these objectives (Schweitzer, 2004; Harwood, 2004). This means that the funders are increasingly demanding detailed reports and statistics about the money that has been given to the non-profit organizations. The competition for funds is always growing and funders have the absolute right to choose where their money goes based on the proven results given by the respective organization. From the public's point of view, they want it all. The public wants to be assured that their money is going where it should go and that someone is checking to make sure that non-profit organizations are spending their money wisely.

In addition, there is a lack of studies examining the mechanism of accountability and practices in NPOs in Malaysia. Furthermore, academic research regarding the accountability of NPOs also lags behind the rapid development of public, governmental and business interests in this area (O'Dywer and Unerman, 2008). Thus, this study focuses on the organizational characteristics and accountability in NPOs in Malaysia, which will provide a significant contribution to the knowledge and the public at large.

\subsection{Resource Dependency Theory}

In the past twenty-five years, the Resource Dependency Theory (RDT) has often been the platform for examination of how NPOs survive and perform (Pfeffer and Salancik, 1978; Miller-Millesen, 2003). Specifically, Pfeffer and Salancik (1978) introduced the RDT to explain how an organization's strategy, structure, and survival depend on its resources and dependency on external institutions. They briefly explained the applicability of RDT in that, "the key to Organizational survival is the ability to acquire and maintain resources".

The earliest literature stressed the importance of the resources that a firm control as being vital for its growth (Penrose, 1959). Such resources include all assets, capabilities, organizational processes, firm attributes, information, and knowledge controlled by a firm, in order to improve the efficiency and effectiveness of the firm (Barney, 1991).

The level of dependency increases as the resources provided become more important and more concentrated (Froelich, 1999). This means that as the organizations focus more on one or very few resources, their level of dependency on that one or few resources is likely to be very high. As for NPOs, their sources of income normally come from government grants, donations and subscription fees (Verbruggen, Christiaens and Milis, 2011). Therefore, their dependency on outside resources makes them accountable and transparent, as 
the fund provider is highly demanding concerning the availability and honesty of the information provided.

The study by Galaskiewicz and Biefield (1998) also stated that an organization's future depends on its access to resources. To ensure its success, an organization needs to properly manage its flow of resources by maintaining autonomy and managing its dependency on external resources (Fernandez, 2008; Hager, Glaskiewicz, and Larson, 2004). The structure of revenue, as evidenced by NPOs, demonstrates one of the ways to interpret the way organizations behave (Anheier, Toepler and Wojciech Sokolowski, 1997).

Thus, as the RDT suggests, funding sources in non-profits appear to be an important and consistent predictor of strategy, accountability and performance. In addition, consistent with the RDT perspective, Hodge and Piccolo, (2005) suggested that flexibility with resources has a positive influence on an organization's financial stability and accountability. Thus, in order to survive, the board of directors should implement some very good activities and programmes to enhance the organization's private fundraising efforts.

\subsection{Donation and Accountability}

Most of the NPOs depend on public donations, government funding and other types of fund, thus reflecting that NPOs are accountable to multiple stakeholders. The increasing number of NPOs indicates that the competition for funds is constantly growing. Hence, it is paramount that an NPO is seen as being accountable in order to maintain the trust of the various stakeholders. The loss of trust can potentially reduce an organization's ability to attract or maintain donors, and affect its ability to communicate with other organizations and its reputation as a legitimate NPO. This infers that NPOs need to be concerned about the issue of accountability to their various stakeholders.

As accountability means different things to different stakeholders (Doyle, 2005), it is only possible for NPOs to fulfil their obligations to ensure that the organization is accountable to the multiple stakeholders. Trussel and Parsons (2008) found that certain characteristics of NPOs are associated with the decisions concerning donations. This, in turn, suggests that NPOs must be accountable to maintain the trust of the stakeholders that provide the funds needed for NPOs to achieve their mission.

Based on the premise that donors demand adequate information to make donation decisions, this study expects a positive relationship between the funds generated from other activities and the extent of accountability. The increasing calls for transparency in the non-profit sector indicate that donors need information that provides assurance regarding the reputation of NPOs. In keeping with this argument, the following hypothesis is developed:

H1: There is a significant positive relationship between the income generated from donations and the extent of accountability of non-profit organizations. 


\subsection{Grants and Accountability}

One of the main sources of revenue for NPOs is grants. In Malaysia, there are two types of grant - government and institutional. In order to encourage individuals and the government to contribute grants, researchers have outlined a standard for them to consider before giving any donation or grant. However, there is a significant relation between transparent financial accounting information and the total given (Gordon and Khumawala, 1999; Tinkelman, 1999).

This means that if the donors and grantors are satisfied with the information they obtain from an NPO, their confidence in the sector may be preserved. The study of Buchheit and Parsons (2006) provided some evidence that voluntary disclosure, and good accountability and transparency are effective for maintaining confidence in the NPO. Burger and Owens (2010) also stated that NPOs funded by government grants are more likely to be accountable. The stakeholders, including the grantors and donors, most likely require favourable financial reports or some feedback before making any decision. Hence, organizations that have grants may have more incentive to keep good financial records and make these available to the public upon request, and appear transparent and accountable.

H2: There is a significant positive relationship between the income generated from grants and the extent of accountability of non-profit organizations.

\section{Methodology}

\subsection{Sample Selection and Data Collection}

The sample of this study was selected from the companies registered with the CCM. The data were acquired from the annual reports and the Borang Maklumat Kewangan (BMK). The annual reports contain financial information, as well as information pertaining to a NPO's directors and programme of services. While the BMK contains additional information about NPOs, such as details concerning their bank information and annual expenditure. The sample of the study comes from the NPOs registered with the CCM for the year 2011. NPOs in Malaysia are classified by category of which there are 13; as classified by the CCM. This study randomly selects organizations from the 13 categories, such as education, recreation, health, sports, and other categories for the year 2011. The final sample used in this study is 219 NPOs.

\subsection{Dependent Variable}

The dependent variable in this study is the accountability disclosure index of the governance of the NPO. The accountability disclosure index of the governance practices refers to the dimensions of strategic accountability, fiduciary accountability, procedural accountability, financial accountability and best practices, which were developed by previous researchers (Dhanani, 2012; Ebrahim, 2007; 2010). 
The scoring approach used in this study is based on a dichotomous measure in which an item scores one if it is disclosed and zero if it is not disclosed in the annual report (Chau and Gray, 2002; Cooke, 1989; Gray, Meek and Roberts, 1995). In assessing the applicability of a particular item, the entire annual report is read to make sure that no similar information can be found in any part of the annual report before a judgment is made on the matter. The total score of the accountability index represents the number of points scored by an organization using an ordinal measure of the extent of disclosure for each organization.

Furthermore, Chow and Wong-Boren (1987) suggested that the use of a weighted or unweighted disclosure index is interchangeable because they found almost equivalent results using either type of index. Last but not least, the approach employed and adopted in several prior studies on disclosure (Haniffa and Cooke, 2005; Gray et al., 1995) also supports the scoring approach using unweighted disclosure index in this study.

\subsection{Donations}

NPOs receive income mainly through the funds generated from specific activities, such as membership fees and rental income, as well as funds from the activities of other NPOs. In addition, funds are also donated by external organizations, such as from the government and other institutions. As the initial existence of NPOs is more towards serving the community they are not profit oriented. This study will use a similar approach to that taken by Tinkelmen (1999) that measures the donations as the natural log of total donations.

\subsection{Grants}

Government grantors and indirect donors serve as monitors of NPOs, subjecting recipient organizations to increased reporting and auditing requirements (Trussel, 2008). Public donors may look to expert donors like government grantors to evaluate a NPO's performance. (Tinkelman, 1999). For the purpose of this study, grants will be measured as the natural log of total government grants, which is a similar approach used by Trussel (2008) in his study.

\subsection{Control Variable}

Past literature indicates that large organizations tend to perform better and are more flexible in managing the firm (Wan Mohamad and Sulong, 2010). In addition, total assets are considered as a variable pertaining to the size of the organization (Ashley and Faulk, 2010). Thus, it is anticipated that the larger the total assets possessed by an organization, the more the organization is likely to increase its performance. 


\subsection{Regression Equations}

$$
\text { ACCTB }=\beta_{0}+\beta_{1} D O N A T I O N+\beta_{2} \text { GRANT }+\beta_{3} S I Z E+\varepsilon_{t}
$$

Where, DONATION is the log of total donations; GRANT is the log of total grants; SIZE is the log of total assets (control variable); $\varepsilon$ is the error term.

\section{Findings}

\subsection{Descriptive Statistics}

From the 219 samples selected, the mean value of the accountability index was 0.6934 and ranged from the minimum score of 0.44 to 0.88 out of a possible maximum score of 100 per cent. Thus, it shows that the accountability of NPOs scored was only 69.34 per cent (\%) out of maximum score of 100 per cent.

Table 1: Descriptive Statistics for Dependent Variable

\begin{tabular}{lrrrrr}
\hline & Range & Minimum & Maximum & Mean & Std. Dev. \\
\hline$A C C T B(\%)$ & .44 & .44 & .88 & .6934 & .08413 \\
\hline ACCTB represents Accountability score & in accountability inder. & & &
\end{tabular}

ACCTB represents Accountability score in accountability index.

Table 2: Descriptive Statistics for Independent Variables

\begin{tabular}{lrrrrr}
\hline & $\begin{array}{r}\text { Range } \\
\text { ('000) }\end{array}$ & $\begin{array}{r}\text { Minimum } \\
\left({ }^{\circ} 000\right)\end{array}$ & $\begin{array}{r}\text { Maximum } \\
\left({ }^{\prime} 000\right)\end{array}$ & $\begin{array}{r}\text { Mean } \\
\text { ('000) }\end{array}$ & $\begin{array}{r}\text { Std. Dev. } \\
\text { ('000) }\end{array}$ \\
\hline DONATION & $20,715.30$ & 0 & $20,715.30$ & 927.54 & $2,679.91$ \\
GRANT & $40,236.43$ & 0 & $40,236.43$ & 897.03 & $3,649.85$ \\
SIZE & $1,042,938.18$ & 9.21 & $1,042,938.18$ & $24,006.05$ & $104,212.81$ \\
\hline
\end{tabular}

Legend: DONATION represents donations, GRANT represents grants, and SIZE represents organization size.

From table 3, it can be seen that the mean value for donations is RM927,536.64 with the minimum value being RM0.0 and the maximum RM20,715,298.70. This indicates that not all the organizations received donations as their income. This situation is similar to the grant income, which reported a mean of RM897,028.46 with the minimum and maximum values of RM0.0 and RM40,236,427.70, respectively. While, for the control variable, size, the minimum value of assets for the NPO is RM9,208 and the maximum value RM1,042,938,178.90.

\subsection{Multivariate Test}

Table 3: Coefficient Table

\begin{tabular}{llll}
\hline Model & Beta & $t$ & Sig. \\
\hline (Constant) & & -.163 & .871 \\
DONATION & .067 & 1.031 & .304 \\
GRANT & .017 & .276 & .783 \\
SIZE (Control Variable) & .323 & 4.622 & $.000 * * *$ \\
Adjusted R square & .282 & \\
F & $18.145 * * *$ & \\
\hline *Significant at 10\% level (1-tailed test); **Significant at 5\% level (1-tailed test); ***Significant at 1\% level (1-tailed test.) \\
Legend: DONATION represents donations, GRANT represents grants, and SIZE represents organization size.
\end{tabular}


Table 3 shows the results for accountability; the adjusted R square indicates that 28.20 per cent $(\%)$ of the variation in the accountability could be explained by the board and organizational characteristics of NPOs. The results show a large $\mathrm{F}$ value of 18.145 , which indicates that the variation in the accountability could be explained by the regression and the model. The results in table 4.8 show that the $\mathrm{F}$ value is 18.145 and that the $p$ value is 0.00 . Thus, this study provides evidence that the model in this study is valid. Two main hypotheses were developed in this study. The results of the study to test the hypotheses are discussed in detail below:

$i$. Relationship between donations and the extent of accountability in nonprofit organizations.

Hypothesis one $\left(\mathrm{H}_{1}\right)$ expected that for donations there would be a significant positive relationship between the income generated from donations and the extent of accountability of NPOs. This is because most of the NPOs are dependent on public donations, government funding and other types of fund, which reflects that NPOs are accountable to multiple stakeholders. Hence, it is paramount that an NPO is seen as being accountable in order to maintain the trust of the various stakeholders. This infers that NPOs need to be concerned about the issue of accountability to their various stakeholders. The regression results in Table 4 show that there is no association between the proportion of donations with the extent of the accountability of the organization ( $>0.10)$, 0.304 . This indicates that the income derived from donations for NPOs does not influence the accountability of the organizations. Therefore, $\mathrm{H} 1$ is rejected.

ii. Relationship between grants and the extent of accountability in nonprofit organizations.

Hypothesis two $\left(\mathrm{H}_{2}\right)$ inferred that there is a significant positive relationship between the income generated from grants and the accountability of NPOs. This is because previous studies explained that if donors and grantors are more comfortable with the information they obtain from NPOs, the confidence in the sector may be preserved. In their study, Buchheit et al. (2006) provided some evidence that voluntary disclosure, and good accountability and transparency are effective for maintaining confidence in the NPOs. Burger et al. (2010) also added that NPOs funded by government grants are more likely to be accountable. The stakeholders, including the grantors and donors, most likely require favourable financial reports or some feedback before making a decision. However, the regression results show that there is no association between the grants and the extent of the accountability of the organizations ( $>0.10), 0.783$. This indicates that the grant income for NPOs does not influence the accountability of the organizations. Therefore, $\mathrm{H} 2$ is rejected.

Organizational characteristics, and donations and grants received have no association with the extent of accountability of NPOs. This situation shows that people or organisations might give donations or grants generously without looking at the accountability of the organization. In addition, for the control 
variables, based on the findings, organization size (SIZE) shows a significant relationship with the extent of accountability. This shows that organizations with huge assets might influence the extent of accountability in NPOs; this is consistent with the study of Ashley and Faulk (2010).

\section{Conclusion}

The focus of this study was to establish an understanding of the organizational characteristics as a monitoring mechanism of an organization and their impact on the extent of accountability of the NPOs in Malaysia. The extent of accountability of NPOs is assessed based on two variables, namely, donations and grants. Several statistical analyses were conducted to test the hypotheses including descriptive analysis, correlation and multiple regression analysis.

Hypothesis one predicted that organizations with a high income generated from donations could help to enhance the extent of accountability in the organization. However, this study found an insignificant association between donations and grants, and the extent of accountability of a NPO. This finding is inconsistent with Burger et al. (2010) and Buchheit et al. (2006) who found that NPOs funded by grants are more likely to be accountable. The stakeholders, including the grantors and donors, will most likely require favourable financial reports or some feedback before making a decision. Thus, Hypothesis 1 and Hypothesis 2 are rejected.

Overall, the findings provide useful information and give more input to the various regulatory authorities and other relevant stakeholders regarding the accountability disclosure of NPOs in Malaysia. The findings of this study are subject to certain limitations that could help provide initiatives for future research. For example, the sample size is limited to a one-year observation, which is 2011, for 219 organizations. The findings would be more beneficial if more year period data are used so that the explanatory power of the results can be improved. A wider sample, more years and wider focus on all NPOs could lead to a conclusive result in the future.

The research instrument used in this study is content analysis. Instead of utilizing content analysis as the approach to gather information, other methods, such as in-depth interviews with boards of directors and questionnaires could be considered. Nevertheless, despite these limitations, this study provides useful insights and improves the understanding of the relationships between various organizational characteristics for enhancing the extent of accountability of NPOs in Malaysia.

\section{References}

Anheier, H. K., Toepler, S., \& Wojciech Sokolowski, S. (1997). The implications of government funding for non-profit organizations: three propositions. International Journal of Public Sector Management, 10(3), 190-213. 
Ashley, S., \& Faulk, L. (2010). Nonprofit competition in the grants marketplace. Nonprofit Management and Leadership, 21(1), 43-57.

Barney, J. (1991). Firm resources and sustained competitive advantage. Journal of management, 17(1), 99-120.

Brown, L. D. (2008). Creating credibility, legitimacy and accountability for transnational civil society. Sterling: Kumarian Press.

Brown, L. D., \& Moore, M. H. (2001). Accountability, strategy, and international nongovernmental organizations. Nonprofit and Voluntary Sector Quarterly, 30(3), 569-587.

Bucheit, S., \& Parsons, L. M. (2006). An Experimental Investigation of Accounting Information's Influence on the individual Giving Process. Journal of Accounting and Public Policy, 25, 666-686.

Burger, R., \& Owens, T. (2010). Promoting Transparency in the NGO Sector: Examining the Availability and Reliability of Self-Reported Data. World Development, 38(9), 1263-1277.

Chau, G. K., \& Gray, S. J. (2002). Ownership structure and corporate voluntary disclosure in Hong Kong and Singapore. The International journal of accounting, 37(2), 247-265.

Chow, C. W., \& Wong-Boren, A. (1987). Voluntary financial disclosure by Mexican corporations. Accounting review, 533-541.

Cooke, T. E. (1989). Voluntary corporate disclosure by Swedish companies. Journal of International Financial Management \& Accounting, 1(2), 171195.

Dhanani, A., \& Conolly, C., (2012). Discharging not for profit accountability: UK Charities and public disclosure. Accounting, Auditing \& Accountability Journal, 25(7), 1140-1169.

Doyle, L. M. (2005). Nonprofit Board Accountability: A Literature Review and Critique. SPNA Review, 1(1).

Ebrahim, A. (2010). The Many Faces of Nonprofit Accountability. Harvard Business School.

Ebrahim, A., \& Weisband, E. (2007). Global Accountabilities: Participation, Pluralism and Public Ethics. UK: Cambridge University Press.

Fernandez, J. J. (2008). Causes of dissolution among Spanish nonprofit associations. Nonprofit and Voluntary Sector Quarterly, 37(1), 113-137.

Froelich, K. A. (1999), Diversification of Revenue Strategies: Evolving Resource Dependence in Nonprofit Organizations." Nonprofit and Voluntary Sector Quarterly, 28(3), 246-268.

Galaskiewicz, J., \& Bielefeld, W. (1998). Nonprofit organizations in an age of uncertainty: A study of organizational change. Transaction Publishers.

Gordon, T. P., \& Khumawala, S. B. (1999). The demand for not-for-profit financial statements: A model of individual giving. Journal of Accounting Literature, 18, 31.

Gray, S. J., Meek, G. K., \& Roberts, C. B. (1995). International capital market pressures and voluntary annual report disclosures by US and UK 
multinationals. Journal of International Financial Management \& Accounting, 6(1), 43-68.

Hager, M. A., Galaskiewicz, J., \& Larson, J. A. (2004). Structural embeddedness and the liability of newness among nonprofit organizations. Public Management Review, 6(2), 159-188.

Haniffa, R. M., \& Cooke, T. E. (2005). The impact of culture and governance on corporate social reporting. Journal of accounting and public policy, 24(5), 391-430.

Harwood, R. (2004). The Sustainable Nonprofit. Philantrophy News Digest. Retrieved from www.fdncenter.org.

Hodge, M.M. Piccolo, R.F. (2005). Funding source, board involvement techniques, and financial vulnerability in nonprofit organizations: a test of resource dependence. Nonprofit Management \& Leadership, 16(2), 171190.

Leat, D. (1988). Voluntary Organisations and Accountability. National Council for Voluntary Organisations: London.

Miller-Millesen, J. L. (2003). Understanding the Behavior of Nonprofit Boards of Directors: A Theory-Based Approach. Nonprofit and Voluntary Sector Quarterly, 32(4), 521-547.

O'Dweyer, B., \& Unerman, J. (2008). The Paradox of greater NGO Accountability: A case study of Amnesty Ireland. Accounting, Organisations and Society, 33, 801-824.

Penrose, E. T. (1959). The theory of the growth of the firm. New York: Wiley.

Pfeffer, J., \& Salancik, G. (1978). The External Control of Organisations, A Resource Dependence Perspective. New York: Harper and Row.

Schweitzer, C. (2004). The board Balancing Act. Association Management, 56, 4-40.

Shmitz, H.P., Raggo, P., \& Vijfeiken, T. B. (2011). Accountability of Transnational NGOs: Aspirations vs. Practice. Nonprofit and Voluntary Sector Quarterly, 1-20.

Tinkelman, D. (1999). Factors affecting the relation between donations to nonprofit organizations and an efficiency ratio. Research in Government and Nonprofit Accounting, 10, 135-161

Trussel, J. M., \& Parsons, L. M (2008). Financial Reporting Factors Affecting Donations to Charitable Organisations. Advance in Accounting, 23, 263285.

Verbruggen, S., Christiaens, J., \& Milis, K. (2011). Can resource dependence and coercive isomorphism explain nonprofit organizations' compliance with reporting standards? Nonprofit and Voluntary Sector Quarterly, 40(1), $5-32$.

Wan Mohamad, W. I. A., \& Sulong, Z. (2010). Corporate governance mechanisms and extent of disclosure: Evidence from listed companies in Malaysia. International Business Research, 3(4), 216-228. 